\title{
URGENSI PENDAFTARAN PADA TANAH YANG BELUM BERSERTIFIKAT
}

\author{
Ningrum Ambarsari; Noor Azizah \\ Fakultas Hukum Universitas Islam Kalimantan MAAB \\ Jalan Adhyaksa No. 2 Banjarmasin Kalimantan Selatan \\ Email: ningrum74fhuniska@gmail.com; azizahshmh@yahoo.com
}

\begin{abstract}
The urgency of land registration for the first time on land that has not been certified is intended to realize the orderly administration and legal certainty for landowners. This is because the implementation of land registration will produce a final product that is a certificate as a proof of ownership of land rights. This research aims to determine how the first land registration on land that has not been certified and how obstacles in the first Land registry. This research is expected to make a meaningful contribution. Theoretically, this research is beneficial for the development of legal sciences, especially regarding agrarian law.
\end{abstract}

Keynote: Agrarian, Land Registration, Certified Land.

\section{Abstrak}

Urgensi Pendaftaran Tanah untuk Pertama Kali pada Tanah yang belum Bersertifikat dimaksudkan untuk mewujudkan tertib administrasi dan kepastian hukum bagi pemilik tanah. Hal ini karena penyelenggaraan pendaftaran tanah akan menghasilkan suatu produk akhir yaitu berupa sertifikat sebagai tanda bukti kepemilikan hak atas tanah. Penelitian ini bertujuan untuk mengetahui bagaimana pendaftaran tanah yang pertama kali pada tanah yang belum bersertifikat dan bagaimana kendala - kendala dalam Pendaftaran tanah yang pertama kali. Penelitian ini diharapkan dapat memberikan kontribusi yang sangat berarti. Secara teoritis penelitian ini bermanfaat untuk kepentingan pengembangan Ilmu hukum, khususnya mengenai Hukum Agraria.

Kata Kunci: Agraria, Pendaftaran Tanah, Sertifikat Tanah.

\section{LATAR BELAKANG MASALAH}

Undang-Undang Pokok Agraria

(UUPA) bertujuan memberikan kepastian hukum berkaitan dengan alas hak atas tanah yang dipegang oleh warga negara Indonesia. Berkaitan dengan hal tersebut secara tegas diatur dalam Pasal 19 ayat (1) UUPA yang menyatakan bahwa:

"Untuk menjamin kepastian hukum oleh Pemerintah diadakan pendaftaran tanah diseluruh wilayah Republik Indonesia menurut ketentuan-ketentuan yang diatur dengan Peraturan Pemerintah".

Pendaftaran tersebut meliputi:

a. Pengukuran, perpetaan dan pembukuan tanah;

b. Pendaftaran hak-hak atas tanah dan peralihan hak-hak tersebut; dan

c. Pemberian surat-surat tanda bukti hak, yang berlaku sebagai alat pembuktian yang kuat. 
Pendaftaran tanah diselenggarakan dengan mengingat keadaan Negara dan masyarakat, keperluan lalu lintas sosial ekonomi serta kemungkinan penyelenggaraannya. Tanah merupakan hajat hidup setiap orang, itu benar adanya. Setiap jengkal tanah di mata hukum keagrariaan harus jelas status hak dan pemegang haknya. Misalnya, tanah hak milik (HM) jelas bukan tanah negara (TN) dan berbeda kriterianya dengan tanah-tanah hak guna bangunan (HGB), hak guna usaha (HGU), dll. Begitupun siapa-siapa saja yang boleh menguasai/memilikinya serta peruntukan penggunaan tanahnya mempunyai kriteria-kriteria yang berbeda. Tanah hak milik ataupun tanah hak-hak lainnya wajib didaftarkan di kantor-kantor pertanahan (BPN).

Bukti bahwa tanah tersebut telah terdaftar adalah sertifikat tanah, yang sekaligus sebagai bukti penguasaan/pemilikan pemegangnya atas tanah tersebut. Itulah alasan mengapa pemerintah mengadakan pendaftaran tanah dan penerbitan sertifikat merupakan salah satu perwujudan dari tujuan pendaftaran tanah dimaksud. Undang-Undang Nomor 5 Tahun 1960 tentang Peraturan Dasar Pokok-Pokok Agraria atau disebut juga dengan nama UUPA (Undang- Undang Pokok Agraria), melalui pasal 19 mengamanatkan bahwa pemerintah mengadakan pendaftaran tanah untuk seluruh wilayah RI dan bahwa sertifikat hak atas tanah merupakan bukti yang kuat mengenai suatu penguasaan/pemilikan tanah. Begitupun dengan Peraturan Pemerintah No. 24 Tahun 1997 tentang Pendaftaran Tanah, melalui pasal 3 menjelaskan tujuan dan kegunaan dari pendaftaran tanah dan salah satu produknya bernama sertifikat hak atas tanah tersebut, "Untuk memberikan kepastian hukum dan perlindungan hukum kepada pemegang hak atas suatu bidang tanah, satuan rumah susun dan hakhak lain yang terdaftar agar dengan mudah dapat membuktikan dirinya sebagai pemegang hak yang bersangkutan."

Dalam Peraturan Pemerintah diatur biaya-biaya yang bersangkutan dengan pendaftaran tanah, dengan ketentuan bahwa rakyat tidak mampu dibebaskan dari pembayaran biaya-biaya tersebut. Atas dasar ketentuan di atas maka perlu adanya suatu tindakan oleh pemerintah serta kesadaran masyarakat dalam rangka pendataan tanah yang dimaksudkan agar adanya suatu kepastian hukum bagi pemegang hak milik atas tanah serta pendataan yang lengkap bagi pemerintah dalam tugas sebagai penyelenggaraan negara. Sebagaimana kita ketahui pada saat ini pemerintah terus berupaya untuk 
melaksanakan pendaftaran tanah secara nasional dalam waktu yang singkat, murah dan berhasil. Di samping itu pendaftaran tanah masih harus disesuaikan dengan kondisi sosial ekonomis masyarakat agar pendaftaran tanah dapat terjangkau oleh semua lapisan masyarakat. Pendaftaran tanah dimaksudkan untuk mewujudkan tertib administrasi, tertib hukum dan memenuhi tuntutan masyarakat Indonesia. Penyelenggaraan pendaftaran tanah akan menghasilkan suatu produk akhir yaitu berupa sertifikat sebagai tanda bukti kepemilikan hak atas tanah. Namun dalam pelaksanaannya pastilah ada hambatan baik dalam pelaksanaan administrasi maupun dari kesadaran masyarakat itu sendiri, terlebih lagi bagi masyarakat umum yang belum begitu mengerti akan arti pentingnya suatu pendataan tanah. Maka jelaslah adanya kewajiban yang harus dilaksanakan oleh pemegang hak atas tanah untuk mendaftarkan tanah yang dimilikinya guna mendapatkan bukti otentik yang berkekuatan hukum dengan diterbitkannya suatu sertifikat hak atas tanah oleh lembaga yang berwenang yaitu Badan Pertanahan Nasional.

$$
\text { Dalam masyarakat awam, }
$$
pengetahuan mengenai pendaftaran tanah dan terlebih bagaimana cara memperoleh sertifikat dan cara BPN memproses permohonan sertifikat tanah hampir tergolong bukan pengetahuan umum. Hanya di forum-forum akademiklah beredar pengetahuan semacam ini. Untuk itu adanya penulisan hukum ini juga dapat diapresiasikan sebagai salah satu kepedulian penulis untuk mensosialisasikan pendaftaran tanah dan sertifikasi tanah khususnya dan masalah keagrariaan pada umumnya.

\section{RUMUSA MASALAH}

Berdasarkan latar belakang masalah tersebut, maka rumusan masalah dalam penelitian ini adalah:

1. Bagaimanakah pendaftaran tanah yang pertama kali pada tanah yang belum bersertifikat?

2. Bagainana kendala-kendala dalam pendaftaran tanah yang pertama kali?

\section{METODE PENELITIAN}

Metodologi mempunyai peran yang sangat penting dalam penelitian dan pengembangan pengetahuan karena mempunyai beberapa fungsi antara lain adalah untuk menambah kemampuan para ilmuwan untuk mengadakan atau melaksanakan penelitian secara lebih baik, 
atau lebih lengkap dan memberikan kemungkinan yang lebih besar, untuk meneliti hal-hal yang belum diketahui. ${ }^{1}$

\section{PEMBAHASAN}

\section{Pendaftaran tanah yang pertama kali} pada tanah yang belum bersertifikat

Pengaturan pendaftaran tanah dalam UUPA di atur dalam Pasal 19 UUPA yang berisi :

1. Untuk menjamin kepastian hukum oleh pemerintah diadakan pendaftaran tanah diseluruh wilayah Republik Indonesia menurut ketentuan-ketentuan yang diatur dengan Peraturan Pemerintah.

2. Pendaftaran tersebut dalam ayat 1 pasal ini meliputi:

Pengukuran, perpetaan dan pembukuan tanah; Pendaftaran hakhak atas tanah dan peralihan hakhak tersebut; Pemberian surat-surat tanda bukti hak, yang berlaku sebagai alat pembuktian yang kuat.

Pendaftaran tanah diselenggarakan dengan mengingat keadaan Negara dan masyarakat, keperluan lalu-lintas social ekonomis serta kemungkinan

${ }^{1}$ Soerjono Soekanto, Pengantar Penelitian Hukum, Universitas Indonesia, Cet. 3, Jakarta, 2017, hlm. 7. penyelenggaraannya,

menurut pertimbangan Menteri agraria.

Dalam Peraturan Pemerintah diatur biaya-biaya yang bersangkutan dengan pendaftaran termaksud dalam ayat 1 diatas, dengan ketentuan bahwa rakyat yang tidak mampu dibebaskan dari pembayaran biayabiaya tersebut.

Mengingat pasal 19 ayat (1) UUPA maka Pengaturan pendaftaran tanah di Indonesia yang lebih rinci diatur dalam Peraturan Pemerintah Nomor 24 Tahun 1997 yang ditetapkan dan diundangkan pada tanggal 8 Juli 1997 tentang Pendaftaran Tanah, yang menggantikan PP No.10 Tahun 1961. Dan PP 24/1997 ini baru mulai berlaku tanggal 8 oktober 1997.

Dalam penjelasan umum PP No.24/1997 dikemukakan apa yang menjadi pertimbangan perlunya diadakan peraturan pendaftaran tanah baru yaitu:

"Dalam pembangunan jangka panjang peranan tanah bagi pemenuhan berbagai keperluan akan meningkat, sehubungan dengan itu akan meningkat pula kebutuhan akan dukungan berupa jaminan kepastian hukum di bidang pertanahan. Selain itu dalam menghadapi kasus-kasus konkret 
diperlukan juga terselenggaranya pendaftaran tanah, yang memungkinkan bagi para pemegang hak atas tanah untuk dengan mudah membuktikan haknya atas tanah yang dikuasainya dan bagi para pihak yang berkepentingan dapat memperoleh keterangan yang diperlukan mengenai tanah, serta bagi Pemerintah untuk melaksanakan kebijaksanaan pertanahannya".

Menurut Pasal 2, PP 24/1997 pendaftaran tanah diselenggarakan/dilaksanakan berdasarkan asas sederhana, aman, terjangkau, mutakhir, dan terbuka.

Tujuan dari diselenggarakannya pendaftaran tanah berdasarkan Pasal 3, PP 24/1997 adalah:

a) Untuk memberikan kepastian hukum dan perlindungan hukum kepada pemegang hak atas suatu bidang tanah, satuan rumah susun, dan hak-hak lain yang terdaftar, agar dengan mudah dapat membuktikan dirinya sebagai pemegang hak yang bersangkutan. Untuk itu kepada pemegang haknya diberikan sertifikat sebagai surat tanda buktinya.

b) Untuk menyediakan informasi kepada pihak-pihak yang berkepentingan, termasuk
Pemerintah, agar dengan mudah dapat memperoleh data yang diperlukan dalam mengadakan perbuatan hukum mengenai bidangbidang tanah dan satuan-satuan rumah susun yang sudah terdaftar.

c) Untuk terselenggaranya tertib administrasi pertanahan. Terselenggaranya pendaftaran tanah secara baik merupakan dasar dan perwujudan tertib administrasi di bidang pertanahan.

Dalam Pasal 1, PP 24/1997 diberikan rumusan mengenai pengertian pendaftaran tanah. "Pendaftaran Tanah adalah rangkaian kegiatan yang dilakukan oleh Pemerintah secara terus-menerus, berkesinambungan dan teratur, meliputi pengumpulan, pengolahan, pembukuan dan penyajian serta pemeliharaan data fisik dan data yuridis, dalam bentuk peta dan daftar, mengenai bidang-bidang tanah dan satuansatuan rumah susun, termasuk pemberian sertifikat sebagai surat tanda bukti haknya bagi bidang-bidang tanah yang sudah ada haknya dan hak milik atas satuan rumah susun serta hak-hak tertentu yang membebaninya".

Pelaksanaan pendaftaran tanah meliputi kegiatan pendaftaran tanah untuk pertama kali (initial registration) dan 
pemeliharaan data pendaftaran tanah (maintenance).(Pasal 11, PP 24/1997).

Pendaftaran tanah untuk pertama kali dilaksanakan melalui pendaftaran tanah secara sistematik dan pendaftaran tanah secara sporadik. Pendaftaran tanah secara sistematik adalah kegiatan pendaftaran tanah untuk pertama kali yang dilakukan secara serentak yang meliputi semua objek pendaftaran tanah yang belum didaftar dalam wilayah atau bagian wilayah suatu desa/kelurahan. Pendaftaran tanah secara sporadik adalah kegiatan pendaftaran tanah untuk pertama kali mengenai satu atau beberapa objek pendaftaran tanah dalam wilayah atau bagian wilayah suatu desa/kelurahan secara individual atau massal.

Pendaftaran tanah secara sistematik diutamakan, karena melalui cara ini akan dipercepat perolehan data mengenai bidang-bidang tanah yang akan didaftar daripada melalui pendaftaran tanah secara sporadik. Disamping pendaftaran tanah secara sistematik, pendaftaran tanah secara sporadik juga akan ditingkatkan pelaksanaannya, karena dalam kenyataannya akan bertambah banyak permintaan untuk mendaftar secara individual dan missal yang diperlukan dalam pelaksanaan pembangunan, yang akan makin meningkat kegiatannya.
Pemeliharaan data pendaftaran tanah adalah kegiatan pendaftaran tanah untuk menyesuaikan data fisik dan data yuridis dalam peta pendaftaran, daftar tanah, daftar nama, surat ukur, buku tanah dan sertifikat dengan perubahan-perubahan yang terjadi kemudian. Agar data yang tersedia di kantor pertanahan selalu sesuai dengan keadaan yang mutakhir,dalam pasal 36 ayat (2) PP 24/1997 ditentukan, bahwa para pemegang hak yang bersangkutan wajib mendaftarkan perubahan-perubahan yang dimaksudkan kepada kantor pertanahan.

Ini sesuai dengan asas mutakhir pendaftaran sebagaimana yang dinyatakan dalam pasal 2, PP 24/1997. Asas mutakhir menuntut dipeliharanya data pendaftaran tanah secara terus-menerus dan berkesinambungan., sehingga data yang tersimpan di kantor pertanahan selalu sesuai dengan keadaan nyata di lapangan, dan masyarakat dapat memperoleh keterangan mengenai data yang benar setiap saat.

Data yang dihimpun dalam pendaftaran tanah meliputi dua bidang yaitu:

1. Data fisik mengenai tanahnya: lokasinya, batas-batasnya, luasnya bangunan dan tanaman yang ada di atasnya. 
2. Data yuridis mengenai haknya: haknya apa, siapa pemegang haknya, ada atau tidak adanya hak pihak lain.

(1) Bidang-bidang tanah yang dipunyai dengan hak milik, hak guna usaha, hak guna bangunan dan hak pakai;

(2) Tanah hak pengelolaan;

(3) Tanah wakaf;

(4) Hak milik atas satuan rumah susun;

(5) Hak tanggungan; Dan

(6) Tanah Negara.

Ada dua macam sistem pendaftaran tanah, yaitu sistem pendaftaran akta dan sistem pendaftaran hak. Sistem pendaftaran tanah mempermasalahkan apa yang didaftar, bentuk penyimpanan dan penyajian data yuridisnya serta bentuk tanda bukti haknya.

Sistem pendaftaran yang digunakan adalah sistem pendaftaran hak (registration of titles), hal tersebut tampak dengan adanya buku tanah sebagai dokumen yang memuat data yuridis dan data fisik yang dihimpun dan disajikan serta diterbitkannya sertifikat sebagai surat tanda bukti hak yang didaftar. Pembukuan dalam buku tanah serta pencatatannya pada surat ukur tersebut merupakan bukti, bahwa hak yang bersangkutan beserta pemegang haknya dan bidang tanahnya yang di uraikan dalam surat ukur secara hukum telah didaftar menurut PP 24/1997. Demikian dinyatakan dalam Pasal 29, PP 24/1997.

Sistem publikasi yang digunakan yaitu sistem negatif yang mengandung unsur positif, karena akan menghasilkan surat-surat tanda bukti hak yang berlaku sebagai alat pembuktian yang kuat, seperti dinyatakan dalam Pasal 19 ayat (2) huruf c, Pasal 23 ayat (2), Pasal 32 ayat (2) dan Pasal 38 ayat (2) UUPA. Bukan sistem publikasi negatif yang murni. Sistem publikasi yang negatif murni tidak akan menggunakan sistem pendaftaran hak. Juga tidak aka nada pernyataan seperti dalam pasal-pasal UUPA diatas, yang menegaskan bahwa sertifikat merupakan alat bukti yang kuat.

Dalam Pasal 32 ayat (1) PP 24/1997 dijelaskan bahwa sertifikat merupakan surat tanda bukti hak yang berlaku sebagai alat pembuktian yang kuat mengenai data fisik dan data yuridis yang termuat didalamnya, sepanjang data fisik dan data yuridis tersebut sesuai dengan data yang ada dalam surat ukur dan buku tanah yang bersangkutan. Ini berarti, bahwa selama tidak dapat dibuktikan sebaliknya, dat fisik dan data yuridis yang tercantum didalamnya harus diterima sebagai data yang benar, baik dalam melakukan 
perbuatan hukum sehari-hari maupun dalam berperkara di pengadilan.

Sesuai dengan ketentuan pasal 19 UUPA pendaftaran tanah diselenggarakan oleh pemerintah, dalam hal ini Badan Pertanahan Nasional/BPN.

Pelaksanaan pendaftaran tanah dilakukan oleh Kepala Kantor Pertanahan, dan dalam melaksanakan tugas tersebut Kepala Kantor Pertanahan dibantu oleh Pejabat Pembuat Akta Tanah (PPAT) dan pejabat lain yang ditugaskan untuk melaksanakan kegiatan-kegiatan tertentu menurut PP 24/1997 ini dan peraturan perundang-undangan yang bersangkuta.

Dalam Pasal 1 angka 24, PP 24/1997 disebut PPAT sebagai pejabat umum yang diberi kewenangan untuk membuat akta-akta tanah tertentu sebagai yang diatur dalam peraturan perundangundangan yang bersangkutan, yaitu akta pemindahan dan pembebanan hak atas tanah dan hak milik atas satuan rumah susun, dan akta pemberian kuasa untuk membebankan hak tanggungan.

Dalam Pasal 7, PP 24/1997 ditetapkan bahwa PPAT diangkat dan diberhentikan oleh Menteri Negara Agraria/Kepala BPN. Dalam penjelasan umum dikemukakan, bahwa akta PPAT merupakan salah satu sumber utama dalam rangka pemeliharaan data pendaftaran tanah.

Pendaftaran untuk pertama kali adalah kegiatan mendaftar untuk pertama kalinya sebidang tanah yang semula belum didaftar menurut ketentuan peraturan pendaftaran tanah yang bersangkutan.

Kegiatan dan pelaksanaan pendaftaran tanah untuk pertama kali meliputi :

1. Pengumpulan dan pengelolaan data fisik;

2. Pengumpulan dan pengolahan data yuridis;

3. Penerbitan sertifikat;

4. Penyajian data fisik dan data yuridis; dan

5. Penyimpanan daftar umum.

Sebagaimana telah dikemukakan bahwa pendaftaran tanah untuk pertama kali dilaksanakan melalui pendaftaran tanah secara sistematik dan pendaftaran tanah secara sporadik.

Pendaftaran tanah secara sistematik dilaksanakan atas prakarsa Badan Pertanahan Nasional yang didasarkan atas suatu rencana kerja jangka panjang dan rencana tahunan yang bersinambungan. Pendaftaran tanah secara sporadik dilaksanakan atas permintaan pihak yang berkepentingan, yaitu pihak yang berhak atas objek pendaftaran tanah yang 
bersangkutan. Yang akan diutamakan adalah pendaftaran tanah secara sistematik, tetapi pendaftaran tanah secara sporadik juga akan ditingkatkan.

Pemeliharaan data pendaftaran tanah dilakukan apabila terjadi perubahan pada data fisik atau data yuridis objek pendaftaran tanah yang telah didaftar.

Pemegang hak yang bersangkutan wajib mendaftrakan perubahan yang bersangkutan kepada kantor pertanahan.(pasal $36 \quad$ PP 24/1997). Pemeliharaan data pendaftaran tanah terdiri dari :

(1) Pemeliharaan data karena pemindahan hak yang tidak melalui lelang;

(2) Pemeliharaan data karena pemindahan hak melalui lelang;

(3) Pemeliharaan data disebabkan peralihan hak karena pewarisan;

(4) Pemeliharaan data disebabkan peralihan hak karena penggabungan atau peleburan perseroan atau koperasi;

(5) Pemeliharaan data karena pembebanan hak;

(6) Pemeliharaan data karena perpanjangan jangka waktu hak atas tanah;
(7) Pemeliharaan data karena pemecahan, pemisahan dan penggabungan bidang tanah;

(8) Pemeliharaan data karena pembagian hak bersama;

(9) Pemeliharaan data karena hapusnya hak atas tanah, hak pengelolaan, dan hak milik atas satuan rumah susun;

(10) Pemeliharaan data karena perubahan nama;

(11) Pemeliharaan data berdasarkan putusan atau penetapan ketua pengadilan;

(12) Pemeliharaan data sehubungan dengan perubahan hak atas tanah

\section{Kendala-kendala Dalam Pendaftaran}

\section{Tanah}

Dalam pendaftaran tanah banyak kendala yang dihadapi oleh masyarakat yang ingin mendaftarkan tanahnya pertama kali. Hal ini terjadi karena masyarakat:

1. Kurang menyadari arti pentingnya tanah, hal ini dapat dilihat bahwa sejauh mereka memiliki tanah yang luas berkaitan kepemilikan alas hak atas tanah tersebut tidak diperhatikan.

2. Kurangnya pengetahuan masyarakat tentang kepastian hukum terhadap bidang tanah yang mereka miliki, karenanya di beberapa wilayah misal daerah trikora di banjarbaru 
banyak kepemilikan tanah yang tumpang tindih. Dalam artian satu bidang tanah pemiliknya bisa lebih dari satu orang.

3. Kurangnyanya sosialisasi dari pihak badan pertanahan setempat mengenai proses pendaftaran tanah. Karena kendala- kendala inilah maka dilapangan masyarakat kesulitan dalam mendaftarakan tanahnya, akibatnya masyarakat membiarkan saja tanahnya tanpa alas hak yang memberikan jaminan kepastian hukum.

Tanpa adanya alas hak terhadap tanah-tanah yang mereka miliki berdampak pada:

1. Banyaknya sengketa tanah, dan pemilik tanah tidak bisa mempertahankan tanah yang dimilikinya karena tidak memiliki bukti yang otentik terhadap tanah yang dimilikinya.

2. Tanah yang mereka miliki yang memiliki nilai ekonomis yang cukup tinggi menjadikan banyaknya pihak lain yang mengincar, terlebih setelah diketahui kepemilikan terhadap alas hak terhadap tanah tersebut tidak adat.

\section{PENUTUP}

\section{Kesimpulan}

1. Tujuan dari diselenggarakannya pendaftaran tanah berdasarkan Pasal 3, PP 24/1997 adalah:

a. Untuk memberikan kepastian hukum dan perlindungan hukum kepada pemegang hak atas suatu bidang tanah, satuan rumah susun, dan hakhak lain yang terdaftar, agar dengan mudah dapat membuktikan dirinya sebagai pemegang hak yang bersangkutan. Untuk itu kepada pemegang haknya diberikan sertifikat sebagai surat tanda buktinya.

b. Untuk menyediakan informasi kepada pihak-pihak yang berkepentingan, termasuk Pemerintah, agar dengan mudah dapat memperoleh data yang diperlukan dalam mengadakan perbuatan hukum mengenai bidangbidang tanah dan satuan-satuan rumah susun yang sudah terdaftar.

c. Untuk terselenggaranya tertib administrasi pertanahan. Terselenggaranya pendaftaran tanah secara baik merupakan dasar dan perwujudan tertib administrasi di bidang pertanahan.

2. Dalam pendaftaran tanah banyak kendala yang dihadapi oleh masyarakat yang ingin mendaftarkan tanahnya pertama kali. Hal ini terjadi karena masyarakat: 
a. Kurang menyadari arti pentingnya tanah, hal ini dapat dilihat bahwa sejauh mereka memiliki tanah yang luas berkaitan kepemilikan alas hak atas tanah tersebut tidak diperhatikan.

b. Kurangnya pengetahuan masyarakat tentang kepastian hukum terhadap bidang tanah yang mereka miliki, karenanya di beberapa wilayah misal daerah trikora di banjarbaru banyak kepemilikan tanah yang tumpang tindih. Dalam artian satu bidang tanah pemiliknya bisa lebih dari satu orang.

c. Kurangnyanya sosialisasi dari pihak badan pertanahan setempat mengenai proses pendaftaran tanah.

\section{Saran}

1. Pendaftaran tanah sebaiknya dilakukan untuk menhindari kemungkinan kehilangan tanah yang dimilki, agar memiliki alas hak yang sah.

2. Sebaiknya dilakukan sosialisasi terhadap masyarakat tentang proses pendaftaran tanah.

\section{DAFTAR PUSTAKA}

\section{Buku}

AP. Parlindungan,1988. Pendaftaran Tanah Tanah dan Konfersi hak milik atas tanah menurut UUPA, Alumni, Bandung.
Bachtiar Effendie, 1993. Pendaftaran Tanah Di Indonesia Dan Peraturan Pelaksanaannya, Alumni, Bandung.

Budi Harsono, 2003. Hukum Agraria Indonesia, Djambatan, Jakarta

Boedi Harsono, 2005. Hukum Agraria Indonesia, Sejarah Pembentukan UUPA, Isi dan Pelaksanaan, Djambatan, Jakarta.

Edy Ruchyat, 1999. Politik Pertanahan Nasional Sampai orde Reformasi, Alumni, Bandung.

Hasan Wargakusumah, 1995. Hukum Agraria I, PT. Gramedia Pustaka Utama, Jakarta.

Soerjono Soekanto, 2007. Pengantar Penelitian Hukum (Jakarta: Penerbit Universitas Indonesia, Cetakan Ketiga).

\section{Peraturan Perundang-undangan}

Undang-Undang Dasar NRI 1945

Undang-Undang Nomor 5 Tahun 1960 Tentang Undang-Undang Pokok Agraria (UUPA)

Peraturan Pemerintah Nomor 10 Tahun 1961 Tentang Pendaftaran Tanah.

Peraturan Pemerintah Nomor 24 Tahun 1997 Tentang Pendaftaran Tanah. 
